\title{
Style of Obama's Bid for the Second Term of the U.S. Presidential Office
}

\section{Samuel Gunawan}

\author{
Petra Christian University; samgun@peter.petra.ac.id
}

\section{Doi:10.5901/mjss.2016.v7n1s1p213}

\begin{abstract}
This article seeks to identify the characteristics of the style of Obama's bid for the second term of the U.S. Presidential office. It examines the central ideas and their respective elaborations into the main ideas in Obama's three speeches: Osawatomie Speech (2011), State-of-the-Union Address (2012), and Virginia Beach Campaign Speech (2012). The research method applied was qualitative content analysis to deconstruct the speeches by means of analytical narratives in the light of some rhetorical strategies, and then some degree of interpretation were done to arrive at the underlying thought of the speeches. In the Osawatomie Speech, Obama underpinned and framed his bid for re-election by citing a blueprint for a stronger American economy built to last. Then through his State-of-the-Union Address, he highlighted his first-term Administration's success in unifying Americans of all backgrounds towards the common good that prompted America to continue going forward. Based on the prior claim of his Administration's success, he drove home his political goal to strengthen further the American economy again by realizing a stronger American middle-class economy. Finally, this message was magnified by his assertion of a plea to reclaim the American Promise through his proposed congruent programs toward a stronger middle-class economy that is built to last in his Virginia Beach Campaign Speech.
\end{abstract}

Keywords: Incumbent president's political communication, Obama's bid for re-election, Obama's American economy that is built to last

\section{Introduction}

In democratic societies, voters may make their decision as to which political candidate to vote based on their judgement of a politician's style and self-presentation. It is for that reason that a politician often builds up his or her style of leadership through a number of ways that help lead to strengthening his or her image. The politician's style and selfpresentation may take many forms, both on physical appearance and verbal prowess. For verbal prowess, politicians rely on the spoken words to communicate their political thought and goals, persuade potential voters, and win their trust (cf. Charteris-Black, 2011, pp. 1, 2). With the advancement of modern media, various styles and self-representation strategies are used by politicians to enlist the winning support of potential voters. This paper focuses on Obama's powerful verbal prowess in the organization of meaning resources in terms of the central ideas and the main ideas in his speeches as part of his political communication styles in his bid for re-election in 2012. Following Verdonk $(2002$, p. 5, 6), the term Obama's "style" in this paper is taken to mean as his distinct way of using language for creating some effect to achieve his political goals. The study is centered on the organization of the meaning resources within the framework of text-building and rhetoric (cf. Becker, 1977: 197-210; cf. Thornborrow, 2002: 8; cf. Hesford \& Brueggemann, 2007).

\subsection{Purpose}

This research is an inquiry into Obama's verbal prowess in the invention of his central ideas and their further elaboration into some sets of main ideas in three of his speeches to communicate his arguments in his bid for the second term of the U.S. Presidential office in 2012.

\subsection{Scope}

The scope of this study is on rhetoric and discourse covering three of Obama's speeches that were carefully worded to communicate his political thought and goal before his re-election.

\section{Literature Review}

It may not have been without any reason that out of the five canons of rhetoric, "invention" was given the first place (cf. 
Beebe \& Beebe, 2009, p. 447; cf. Hesford \& Brueggemann, 2007, pp. 36-40; cf. De Beaugrande \& Dressler, 1990, p. 14; cf. Leith \& Myerson, 1989, p. 15). In the context of political communication, this rhetorical canon underlies the importance of determining "ideas" to be communicated to prospective voters. Those ideas may have the potential capacity to mobilize voters' political actions (cf. Heywood, 2012, pp. 2, 3). In the light of this rhetorical canon of invention, by which a text-maker was to start his or her text-making, this paper used the rhetorical construct of "the central idea of a speech", as "a one-sentence summary of the speech content" (cf. Beebe \& Beebe, 2009, p. 31), as an analytical tool to identify the underlying thought of Obama's political style in three of his speeches undertaken in this study. Analytical narratives were used to deconstruct the scripts of the speeches to arrive at the underlying thought of each speech. The same processes also helped identify the "main points" or "key ideas" as a further development of the central idea in the text-making processes (cf. Beebe \& Beebe, 2009, p. 31). Rhetorically, the over-all styles of Obama's bid for the second term of the U.S. Presidential office were developed based on the determined central ideas. This paper examined how these constructs were used to organize the meaning resources to communicate Obama's lines of thought and political goals in three of his speeches.

Examination of the organization of the meaning resources was also made possible by a long list of useful rhetorical techniques as presented by Leanne (2010) that includes speaking to the audience and establishing common ground for breaking down barriers (pp. 15, 16, 63), achieving transcendence (pp. 42, 43), conveying vision through personalization (p. 17), personalizing the messages (pp. 74-76), referencing to history and familiarity (pp. 48, 49, 82, 83), borrowing words from iconic figures in history (pp. 22, 56, 59), as well as using a crescendo and leaving a strong impression (pp. 18, 19).

\section{Research Methods}

Data sources for this study were Obama's three speeches pronouncing his bid for re-election in 2012: the Osawatomie Economic Speech (Obama, 2011; cf. Reich, 2011), the State-of-the-Union Address of 2012 (Obama, 2012a), and the Virginia Beach Campaign Speech (Obama, 2012b). The research used qualitative content analysis to decipher Obama's central ideas that were then further developed into some sets of main ideas in communicating his political thought and goals (cf. Krippendorff, 2004, pp. 16-30; Schreier, 2013, pp. 1-8, 30). Krippendorff (2004, pp. 16, 17) calls such an approach as being interpretive because it involves a close reading of the speeches and re-articulation (interpretation of the speeches into new analytical narratives), in which the researcher's social and cultural understandings are constitutively involved. As applied, this framework (cf. Krippendorff, 2004, pp. 29, 30) followed some steps such as: deconstructing and examining the content of the speeches; establishing the research questions related to Obama's carefully scripted texts of the rhetorical craft to communicate his persuasive political thought and goals; attempting to make more sense of the texts; making inferences to answer the research questions; and finaly, validating the findings.

In the data analysis, techniques of data reduction occured as the research was to focus on Obama's carefully scripted texts of the rhetorical craft to communicate his persuasive political thought and goals in terms of the central ideas and main ideas in his three speeches expressing his bid for the Presidential re-election in 2012. From that point, the researcher engaged in some degree of interpretation to arrive at the meaning of Obama's style of political communication as spelled out in his speeches' central ideas and main ideas (cf. Schreier, 2013, pp. 4, 30). For validating the result, the researcher presented the topic of this paper in a focus group discussion to enlist some inputs from colleagues majoring in American studies and politics.

\section{Results of the Analysis}

\subsection{Osawatomie Economic Speech: The Central Idea and the Main Ideas}

Two symbolic meanings were foregrounded on why Osawatomie, Kansas, had been chosen as the place to launch Obama's underpinning economic speech (Obama, 2011). As an effective speaker, firstly, Obama used the rhetorical technique of establishing linkages with his audience and speaking to their concern (cf. Leanne, 2010, p. 16). He did not only personalize, but he also connected himself and his messages to the Americans using the patriotic examples of his grandparents who were rooted in Kansas. Obama showed that he was one of the average common people, implying the message that he knew their common problems as well. Secondly, as a technique for establishing common ground with his average audience, he also used words from history that resonated to many. He connected his messages to the iconic figure of Teddy Roosevelt and borrowed his famous phrase "square deal" that is entrenched in the political lexicon (cf. Leanne, 2010, pp. 22, 56, 59). Historically, from this place, Teddy Roosevelt once launched his new nationalism, known 
in his famous phrase "square deal", that is, a policy to provide more opportunities for American citizens and redistribute the wealth for their common good. In the same spirit, by a technique of referencing to history and familiarity that just about every American understood (cf. Leanne, 2010, pp. pp. 48, 49, 82, 83), Obama declared his vision to rebuild the American middle-class economy that had declined. Indeed, the phrase "middle-class" itself was an important tag throughout the speech, as it was often repeated.

Obama was at his best as he conveyed his vision through personalization of the grass-root optimism in the lives of the common people in the USA using patriotic examples in the lives of his grandfather and grandmother from his mother's side. Unfortunately, in Obama's eyes, the same grass-root optimism known as the American values that gave way to the American middle-class economy had long eroded. Though American-manufactured products still have a great reputation in the world, they have failed in giving decent lives for the common people. Fewer people became richer, but more and more had to struggle to survive. Here, Obama showed his ability to transcend his messages for Americans of diverse backgrounds as he showed that he understood the concerns and challenges that the average Americans were facing.

Obama illustrated the prolonged financial crises that had bankrupted the lives of many Americans. He stressed that it was about time to reclaim the American values that gave way to the American middle-class economy through his decisive phrase "a make or break moment" (Obama, 2011) to take real action.

Obama warned the people not to be trapped by his political rival from another political party who was offering another vision for America. He reaffirmed his belief, as a way of increasing his credibility and his audience's trust, that America would be greater together than they were going their own ways. He drove home his political goal to reclaim the American values in his statement that "everyone engages in fair play, everyone gets a fair shot, everyone does their fair share" (Obama, 2011).

Obama underscored the importance of reclaiming the American values. He stated what Roosevelt and his Administration did to overcome social inequalities and exploitation. Roosevelt encouraged the growth of free market. He argued that it only worked out when it had rules of the road and a fair, open, and honest competition to get customers through better service and competitive prices.

Obama applied a rhetorical technique known as leveraging other people's words (cf. Leanne, 2010, pp. 58-62) to establish emotional linkages to his audience when he cited Teddy Roosevelt's phrase as the latter declared his political agenda known as "New Nationalism": a new economic system in which everyone was given the opportunity to show their best. Obama underscored Roosevelt's legacies: maximum working hours per day; a decent pay for women; insurance for the less privileged; reform in politics and progressive income tax. Obama also echoed what Roosevelt stated regarding the fallacy of the trickle-down economy.

Obama pointed out that the trickle-down economy was not suitable in most cases if a stronger American middleclass economy was to be reclaimed. That economy only benefitted fewer and fewer people. It only created inequalities that were against the American values that guaranteed the opportunity to succeed if everybody was willing to do his or her best.

Obama highlighted the fundamental values of an economy suitable to all Americans: America became greater because of their togetherness: a fair play, a fair shot, and a fair share. To reclaim the middle-class economy, everyone had to be guaranteed the opportunity to succeed. Education had to become the national mission. Business had to produce work opportunities with decent wages, but all were unified by regulations from the government that helped business to succeed. This view ensured a fair share of every citizen as reflected in the tax system in order to invest for the middle-class economy. A stronger middle-class economy could only be realized in an economy in which everyone played by the same rule.

Using a crescendo and ending his speech at a high point, thus, leaving his audience impressed and activated to get involved (cf. Leanne, 2010, pp. 181, 182), Obama concluded his speech by reaffirming the spirit of "New Nationalism" as having been declared by his predecessor - Teddy Roosevelt from Osawatomie - that America would go up and down together. Obama underscored his belief that America would rise and succeed.

Based on the deconstruction of the speech in the analytical narrative above, the central idea of Obama's Osawatomie economic speech can be deduced: "America needs to reclaim its values and strengthen its middle-class economy to guarantee an opportunity for everyone to succeed".

A close reading of the organization of the meaning resources in the text of Obama's Osawatomie economic speech enabled identification of thirteen main ideas developed from the central idea above. The main ideas were organized in three main categories - Opening, Body, and Closing - as follows: 
Table 1. The main ideas of Osawatomie Economic Speech

\begin{tabular}{|c|l|}
\hline \multicolumn{2}{|l|}{ OPENING } \\
\hline 1 & Salutation \\
\hline BODY \\
\hline 2 & Grass-root optimism of a nation \\
\hline 3 & Erosion of American legacies \\
\hline 4 & Mounting financial crises \\
\hline 5 & Decisive moment to reclaim the American values \\
\hline 6 & Reclaiming the American values in history \\
\hline 7 & Unemployment and the fallacy of the trickle-down economy \\
\hline 8 & Unfair tax system not supportive of the middle-class economy \\
\hline 9 & Fight against inequalities \\
\hline 10 & Fair play, fair shot, and fair share \\
\hline 11 & Restoring middle-class security \\
\hline 12 & Tax code supportive of the growth of the middle-class economy \\
\hline CLOSING \\
\hline 13 & Rebuilding the American middle-class economy that is meant to last \\
\hline
\end{tabular}

\subsection{State-of-the-Union Address: The Central Idea and the Main Ideas}

President Obama's State-of-the-Union Address was delivered before Congress on January 24, 2012 (Obama, 2012a). In October of the same year, Americans voted for their President. Obama's speech established common ground and linkages to his audience as he underscored the importance of maintaining the unity of Americans of various backgrounds. At the same time, the speech resonated its transcendent message focusing not on the audience's differences but on their commonalities (cf. Leanne, 2010, pp. 42, 43). This was realized in his high proportion of the use of the first person plural pronoun "we" and its corresponding possessive form "our". Obama was at his best when illustrating unity, loyalty and sacrifice to the country (cf. Leanne, 2010, p. 87) by means of a symbolism of the American Armed Forces who wholeheartedly joined hands to accomplish their mission at the very beginning of his speech. This rhetorical technique helped achieve the transcendent message irrespective of American diversities. With the same kind of teamwork, Obama drove home the message that the American people would also be able to achieve their common goal. America would be able to accomplish their better future with its economy that is built to last.

Not only was Obama able to personalize his messages in the patriotic examples of his grandparents, but he was also referencing history while he cited the rise of the American middle-class economy built by the active involvement of the American veterans. His patriotic grandfather was a representative of veterans who was better rewarded by a caring nation by being able to enter the work market upon homecoming; his grandmother was a representative of productive workers in the work force. They represented the grass-rooted optimism of a Nation. This was also used to drive home the notion of success depicted in the American Promise: If one worked hard enough, he or she would deserve a decent life.

Obama foregrounded his defining issue to reclaim the American Promise. He made it very clear that Americans, irrespective of their various backgrounds, had to choose their better future. He underscored the choice between two different fundamental visions of the future of America that would be determined by the presidential election in the following October of the same year. Obama's underpinning idea of rebuilding the American middle-class economy that is meant to last was stated in his undivided American values: a fair shot, and a fair share, and a fair play.

Obama talked about the American economic crises that had been underway long before he took office. However, as he took office and his Administration's policies were beginning to be effective, the state of the Union became stronger by the growth of the workforces. By reclaiming his Administration's success, he established his greater credential and people's better trust, from which he even built a much stronger force as he used the first person pronoun "I" while pronouncing the blueprint for rebuilding the American manufacturing industry.

In this State-of-the-Union Address, Obama reminded Americans of the threat that had been underway to erode the American middle-class economy due to rising inequalities. Therefore, by taking into account the legacies of the American Promise, the government would have to take real actions to create the growth of the American middle-class economy. The so-called American economy was to be built to last on American manufacturing, American energy, the skills of American workers, and the renewal of the American values. From this respect, it was obvious that Obama was laying out his fundamental economic vision that would frame his bid for a second term of the Presidential office. Echoing his predecessor's - John Kennedy's - famous plea, Obama urged business leaders to do whatever they could to bring jobs 
back home, and in return, the government would act out to ensure their success.

Obama remarked about his position when his Administration started, that they were facing economic crises and scarce job opportunities. Even though a number of crises had been successively overcome, big tasks remain to be accomplished. It was for these reasons that Obama made his bid for a second term as the President of the USA. He argued for the reformation of the tax code that would help the growth of the American manufacturing, and the reformation of trade policies that would protect and boost the American trade as well as secure more employment at home. Obama was at his best as he personalized his Administration's attention to overcome the problem of unemployment. This was personalized in the example of Jackie Bray, a single mom and a laid-off mechanic who was re-employed due to a partnership between a company that provided the job and a community college that provided the relevant skills. Obama stated his continued commitment to education and skills training to support high-tech manufacturing. A more comprehensive immigration reform would also be launched to provide opportunities for skilled graduates of different nationalities that had undergone training in the country as they were needed to staff high-tech manufacturing. To win the race for the future, research that lead to new industries and new jobs for Americans would also be given a priority. Again, Obama personalized this in the example of a worker, Bryan Ritterby, who was re-employed in the industry of the future.

Obama's message achieved a transcendence as he used referencing to history when he cited non-partisan infrastructure projects that generated more jobs both during the Great Depression era and after World War II. Such projects benefitted all Americans, both workers and industries. Governmental regulations and the financial system had assisted the free market to work better.

A call to the American values of fair play and shared responsibility would not only protect the American people and economy, but also help overcome the financial crises and invest more for the future. Government would also have to be reformed to be more responsive to the needs of the American people.

To close his remark, Obama reiterated the transcendent message of the unity to all Americans as personalized in men and women in uniform who had served their country together to secure their freedom as a nation. By working together for their common purpose, America was ensured to move forward.

Based on the deconstruction of the speech in the analytical narrative above, the central idea of Obama's State-ofthe-Union Address of 2012 can be gathered as: "Americans need to sustain their unity to enable them to achieve their common goals and to rebuild a strong American economy that is meant to last".

Then, a close reading of the organization of the meaning resources in the text of Obama's State-of-the-Union Address of 2012 enabled the writer to identify seventeen main ideas developed from the central idea above. The main ideas were organized in three main categories - Opening, Body, and Closing - as follows:

Table 2. The main ideas of Obama's State-of-the-Union Address of 2012

\begin{tabular}{|c|l|}
\hline \multicolumn{2}{|l|}{ OPENING } \\
\hline 1 & Unity of all Americans for their common purpose \\
\hline BODY \\
\hline 2 & A stronger union for rebuilding a stronger American economy \\
\hline 3 & Rebuilding American manufacturing \\
\hline 4 & Favorable tax policies for the growth of American manufacturing \\
\hline 5 & Developing the American trade \\
\hline 6 & Strong commitment for employment \\
\hline 7 & Support for better education \\
\hline 8 & Reforming Immigration to support American economy that is built to last \\
\hline 9 & Winning the race for the future: research for innovation \\
\hline 10 & Energy policy: clean, cheap energy leading to new jobs \\
\hline 11 & Projects generating more jobs \\
\hline 12 & More supportive and rewarding government and financial systems \\
\hline 13 & Business regulation reforms \\
\hline 14 & Tax reform \\
\hline 15 & Government reform \\
\hline 16 & Commitment to world peace \\
\hline CLOSING \\
\hline 17 & Unity of all Americans for their common purposes \\
\hline
\end{tabular}




\subsection{Virginia Beach Campaign Speech: The Central Idea and the Main Ideas}

In September 2012, Obama conducted a campaign in Virginia Beach. As usual, Obama began his speech by establishing common ground and linkages to his audience (Obama, 2012b). His acknowledgments of Ricky - a military spouse and herself a military person - a combination of somebody who did a service to secure the nation and a grass-root domestic housewife, served a good icebreaker meant to establish linkages with his potential voters among military families. Obama implored the kind of "new economic patriotism" in his attempt to enlist political support among military families in his bid for a second term of the U.S. President.

He brought to his audience's attention the reality of the campaign season. He reminded them of his earlier campaign for the first term of the Presidential office. At that time, many did not believe in the possibility of change. He mentioned that those people had earlier gathered and supported him because they shared the enduring common values of the "bedrock of the nation" that had been more than 200 years old. Obama was at his best to personalize those values, for instance, in the lives of his patriotic grandfather and ordinary hard-working grandmother from his mother's side. Not the least was his own mother - who, despite being a single parent herself - was able to earn a living, continued her tertiary education, and at the same time, raised her two children. Whereas from Michelle's side, Obama personalized the grass-root enduring values of personal responsibility for something greater. He illustrated Michelle's father, a dedicated water purification worker who did his job responsibly, who was supported by her mother who dedicated her life to guide and raise her two children, Michelle dan Craig. By using these grass-root examples of ordinary people, Obama wanted to highlight the so-called American bargain - the American Promise - the heart of America: Those who were willing to work hard, took responsibility, and then they would not be constrained by the conditions of their birth. Everybody had the opportunity to realize what he or she was dreaming about. This had earlier urged Obama to get into politics, in order to ensure that everybody would be guaranteed the same opportunity. Many people had come to support him because they saw that the American Promise had slipped away from their lives.

Obama reminded them that in his earlier campaign in 2008 for the first term of the U.S. Presidential office, he was motivated to secure the American Dream for generations to come. With the economic and financial crises, for many, lives had become harder, but Obama claimed that his Administration had been effective in overcoming the crises. Therefore, America would have to secure the continuation of the American industry and the creation of more new jobs. He reminded his audience to back him up as America still has many things to do to continue what Obama had done to restore the middle-class economy. Obama urged that all of those became his strong reasons for his bid for the second term of the U.S. Presidential office.

Obama underscored the fundamental visions of running the country and handling the economy, the Democrat vision vs. the Republican vision. Unlike Democrats, Republicans wanted to cut tax for only a few rich people and the abolition of the regulation that would only benefit financial agents, believing that this would trickle down to benefit many more people. America had the experience of following that "top-down" vision and proved to have failed. In contrast, Obama had another vision of the economy: starting from the middle to spread outside and starting from the bottom to spread to the top. Everybody had the same opportunity, the same share, and played by the same rule.

Obama claimed that he had cut and lowered taxes for middle-class families since he came into office. He guaranteed to continue the policy not to raise taxes for small business people and low-income workers based on the philosophical belief that if they were doing well, the country would be doing well too. He would hold the policy that $98 \%$ of Americans earning up to 250,000 would not have their taxes raised; meanwhile, the top $2 \%$ people would not be given a tax break to avoid deficit.

Obama mentioned some reasons for his bid for re-election, among others: to provide better opportunities for education for the young generation, creating more manufacturing jobs, improving better insurance for military families, building better infrastructures, creating clean energy, and reducing deficit. He also implored parents' responsibility to take good care of their children. Referencing history, he showed Clinton's legacy of having been able to reduce deficit and create more new jobs. Obama was convinced that with his bid for re-election, he also believed that many wealthy Americans would be willing to do the right things for their country.

Obama ended his speech with a crescendo and left a strong impression and plea on the part of his prospective audience to vote for him if they wanted America to go forward. Obama was at best to achieve the transcendent message as his bid for re-election was related to everybody's family as a means of getting grass-root support of all Americans, irrespective of their various backgrounds. It sounded greater as he was also referencing history such as what America had done in building infrastructures and in making advancements in science. He put his trust in the decency and the power of the American people to continue the mission that he and the people had started since 2008.

Based on the deconstruction of the speech in the analytical narrative of Obama's campaign speech in Virginia 
Beach above, the central idea is identified: "A plea to fulfill the American Promise by rebuilding the American middle-class economy that is meant to last, and to sustain programs anchored on the principle that everybody has a fair shot, a fair share, and a fair play".

Furthermore, a close reading of the organization of the meaning resources in the text of Obama's Virginia Beach speech campaign enabled the writer to identify eleven main ideas that were developed from the central idea above. Those main ideas were organized in three main categories - Opening, Body, and Closing - as follows:

Table 3. The main ideas of Obama's speech campaign in Virginia Beach

\begin{tabular}{|c|l|}
\hline \multicolumn{2}{|c|}{ OPENING } \\
\hline 1 & Greeting and acknowledgements \\
\hline BODY \\
\hline 2 & Campaign season \\
\hline 3 & The bedrock of the nation \\
\hline 4 & Reclaiming the American Promise \\
\hline 5 & Obama's bid for re-election \\
\hline 6 & Republican vs. Democratic idea of economy \\
\hline 7 & Democratic approach on taxation \\
\hline 8 & Reasons for Obama's re-election \\
\hline 9 & Continuing the job of rebuilding the nation \\
\hline 10 & Going forward with the right vote for Obama \\
\hline CLOSING \\
\hline 11 & Securing the right vote for Obama \\
\hline
\end{tabular}

\subsection{Foregrounded Campaign Messages}

\subsubsection{Foregrounded Central Ideas}

From the earlier discussions on the central ideas of the three speeches, the overall underlying thought of Obama's style of political communication in his bid for the second term of the U.S. Presidential office can be clearly gathered. Based on the discussion on the central idea of Obama's Osawatomie economic speech, it was obvious that the speech was to provide a frame for his bid for the Presidential re-election. Obama focused on the twin important issues: reclaiming the American values and rebuilding the American middle-class economy. In line with the Osawatomie economic speech, through his State-of-the-Union Address of 2012, Obama argued for the importance of maintaining the American unity to enable America to go forward to rebuild the American economy that is meant to last. Through the central idea of his Virginia Beach campaign speech, Obama emphasized that the American Promise can be realized by programs and policies to rebuild the American middle-class economy, in which every body was guaranteed to have a fair shot, a fair share, and a fair play. Therefore, it was obvious that the central ideas of the three speeches undertaken in this study were interrelated, mutually complementary, and mutually supportive.

\subsubsection{Foregrounded Main Ideas}

\subsubsection{Foregrounded Main Ideas in Obama's Osawatomie Economic Speech}

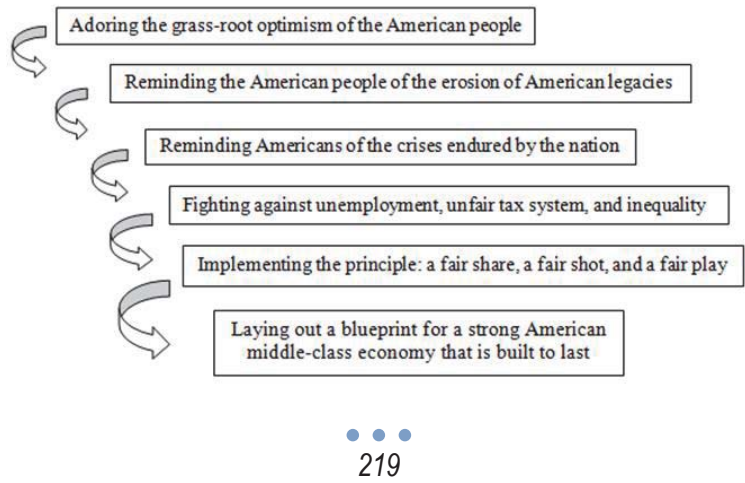




\subsubsection{Foregrounded Main Ideas in Obama's State-of-the-Union Address of 2012}

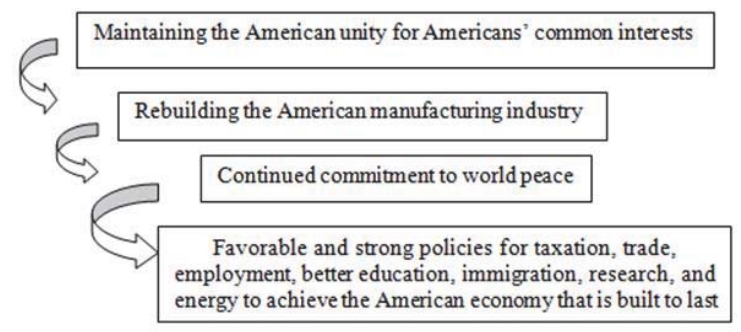

\subsubsection{Foregrounded Main Ideas in Obama's Speech Campaign in Virginia Beach}

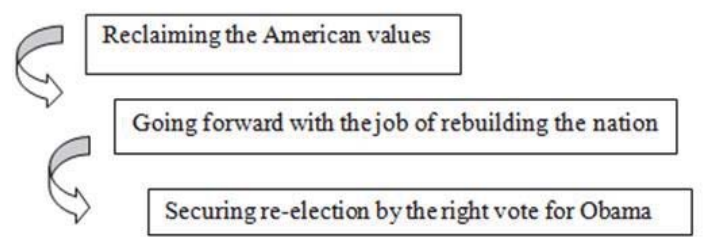

\section{Conclusion}

Based on a scrutiny of Obama's organization of the meaning resources at his disposal in terms of the central ideas and the main ideas of his political speeches undertaken in this study, some insights into his style of political communication in his bid for the second term of the U.S. Presidential office can be gathered as follows:

(1) As a text-maker, Obama built up his texts of speeches to convey meanings that are most essential for his reelection in 2012:

a) He framed his bid for re-election by laying out a blueprint of the American economy that is built to last.

b) He claimed the success of his first-term Administration and for that reason, he underscored the importance of continuing the unity of the American people to enable them to go forward for their common goals of rebuilding the nation.

(2) The foregrounded central ideas of the three speeches undertaken in this study were concerned with:

a) Reclaiming the American values and rebuilding the American middle-class economy.

b) The importance of maintaining the American unity to enable America to go forward to rebuild the American economy that is meant to last.

c) Realizing the American Promise by programs and policies to rebuild the American middle-class economy, in which every body was guaranteed to have a fair shot, a fair share, and a fair play.

(3) The foregrounded main ideas of Obama's three speeches were directed toward the goals of:

a) Laying out a blueprint for a strong American middle-class economy that is built to last.

b) Maintaining the American unity and going forward with the implementation of conducive and strong policies for taxation, trade, employment, better education, immigration, research, and energy to achieve the American economy that is built to last.

c) Reclaiming the American values, going forward with the job of rebuilding the American manufacturing industry by securing Obama's re-election.

(4) Obama's bid for the second term of the U.S. Presidential office was strongly supported by both his cultural and economic frames, that is, reclaiming the American Promise and restoring the middle-class economy.

Last but not the least, to understand the whole range of Obama's style of political communication in his bid for the second term of the U.S. Presidential office, it would be worth having a similar kind of inquiry into Obama's other speeches in the latter part of his campaigns for the second term, covering at least his nomination acceptance speech and Second Inauguration Speech. 


\section{Acknowledgments}

* I wish to thank my colleagues in American studies and politics, especially Gatot Priyowidodo, Ph.D. and Setefanus Suprayitno, Ph.D., for a fruitfull discussion on the rhetoric of American presidential campaign speeches in the focus group discussion.

** I wish to thank SPi Global Professional Editing Service for English language polishing and editing.

\section{References}

Becker, A. (1977). Text-building, epistemology, and aesthetic in Javanese shadow theater. In Alton Becker and A.A. Yengoyan (Eds.), The imagination of reality: Essays in Southeast Asian coherence systems (pp. 197-210). Norwood, N.J.: Ablex Publishing Corporation.

Beebe, S.A. \& Beebe, S.J. (2009). Public speaking handbook. (7th ed.). Boston: Pearson.

Charteris-Black, J. (2011). Politicians and rhetoric: The persuasive power of metaphor. (2nd ed.). New York: Palgrave Macmillan.

De Beaugrande, R. \& Dressler, W. (1981). Introduction to text linguistics. London: Longman.

Hesford, W.S. \& Brueggemann B. (2007). Rhetorical visions. London: Pearson.

Heywood, A. (2012). Political ideologies: An introduction. (5th ed.). Basingstoke: Palgrave Macmillan.

Krippendorff, K. (2004). Content analysis: An introduction to its methodology. Thousand Oaks, California: SAGE Publication.

Leanne, S. (2010). Say it like Obama and win. (Expanded ed.). NY: McGraw Hill.

Leith, D. \& Myerson, G. (1989). The power of address. London: Routledge.

Obama, B. (2011). Full text of President Obama's economic speech in Osawatomie. (Online) Available: http://oxnewsinsider.com/2011/ 12/06/full-text-read-transcript-of-president-obamas-economic-speech-in-osawatomie-kansas/(May 1, 2015)

Obama, B. (2012a). Obama's State-of-the-Union Address. (Online) Available: http://blogs. suntimes.com/sweet/2012/01/ obama_state_ of the union_addres_1.html (May 5, 2015)

Obama, B. (2012b). Obama's Virginia Campaign Speech. (Online) Available: http://historymusings.wordpress.com/2012/07/13/full-textcampaign-buzz-july-13-2012-president-barack-obamas-virginia-campaign-trip-speech/ (June 5, 2015)

Reich, R. (2011, Dec. 7). Obama's most important economic speech. (Online) Available: http://www.csmonitor.com/Business/RobertReich/2011/1207/Obama-s-most-important-economic-speech (Feb. 10, 2015)

Schreier, M. (2013). Qualitative content analysis in practice. Los Angeles: SAGE Publications.

Thornborrow, J. (2002). Power talk: Language and interaction in institutional discourse. Harlow: Pearson Education.

Verdonk, P. (2002). Stylistics. Oxford: Oxford UP. 